\title{
MORC3 Gene
}

National Cancer Institute

\section{Source}

National Cancer Institute. MORC3 Gene. NCI Thesaurus. Code C113140.

This gene is involved in binding to both RNA and nuclear matrix proteins. 